Prepared in cooperation with the Indiana Office of Community and Rural Affairs

\title{
Flood-Inundation Maps for the Wabash River at Lafayette, Indiana
}

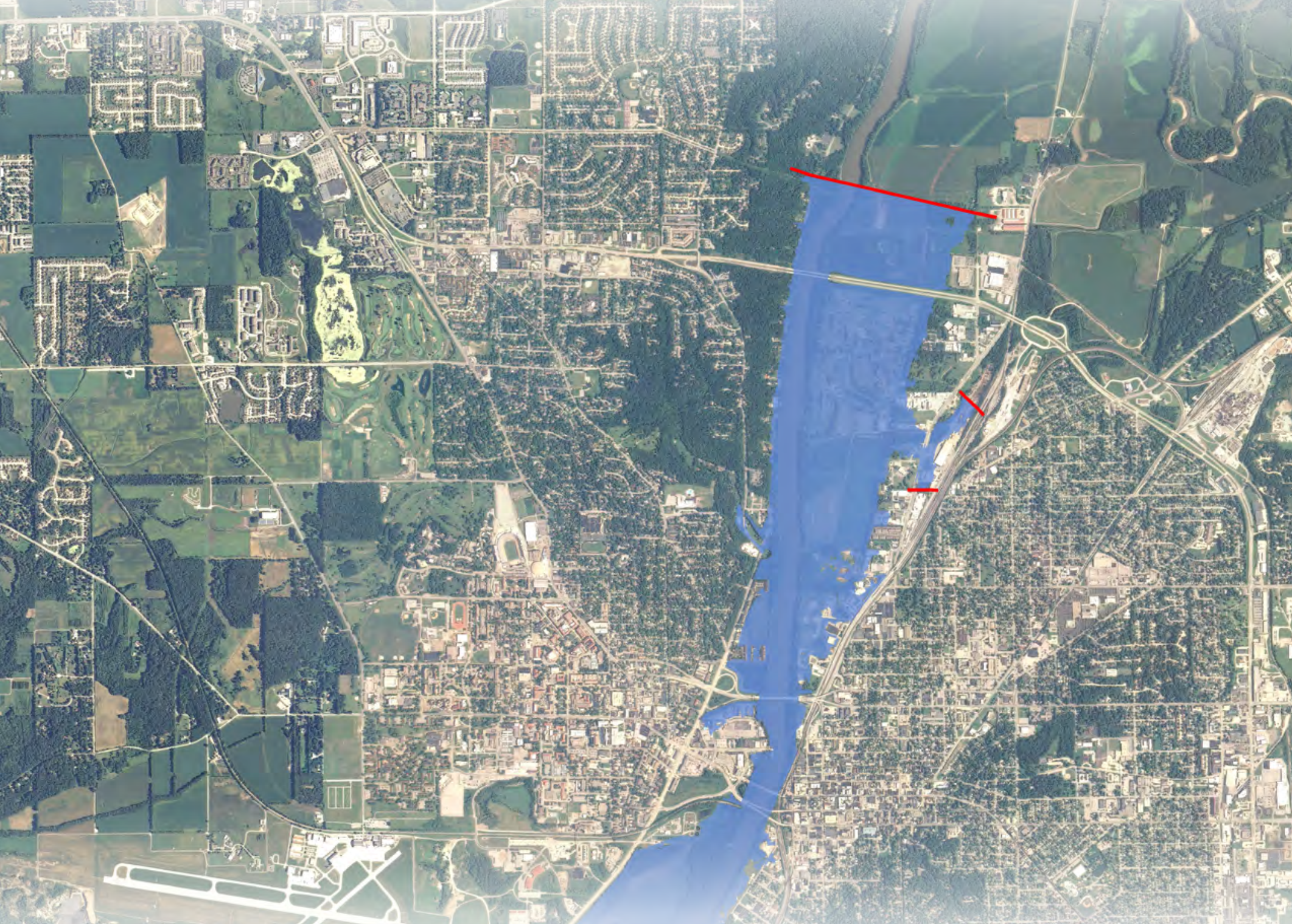

Scientific Investigations Report 2018-5017 
Cover. Example of a flood-inundation map for the Wabash River at Lafayette, Indiana. 


\section{Flood-Inundation Maps for the Wabash River at Lafayette, Indiana}

By Moon H. Kim

Prepared in cooperation with the Indiana Office of Community and Rural Affairs

Scientific Investigations Report 2018-5017 


\title{
U.S. Department of the Interior \\ RYAN K. ZINKE, Secretary
}

\section{U.S. Geological Survey William H. Werkheiser, Deputy Director exercising the authority of the Director}

\author{
U.S. Geological Survey, Reston, Virginia: 2018
}

For more information on the USGS - the Federal source for science about the Earth, its natural and living resources, natural hazards, and the environment-visit https://www.usgs.gov or call 1-888-ASK-USGS.

For an overview of USGS information products, including maps, imagery, and publications, visit https://store.usgs.gov.

Any use of trade, firm, or product names is for descriptive purposes only and does not imply endorsement by the U.S. Government.

Although this information product, for the most part, is in the public domain, it also may contain copyrighted materials as noted in the text. Permission to reproduce copyrighted items must be secured from the copyright owner.

Suggested citation:

Kim, M.H., 2018, Flood-inundation maps for the Wabash River at Lafayette, Indiana: U.S. Geological Survey Scientific Investigations Report 2018-5017, 10 p., https://doi.org/10.3133/sir20185017.

ISSN 2328-0328 (online) 


\section{Acknowledgments}

The author wishes to thank the many local, State, and Federal agencies that have cooperated in the funding for the operation and maintenance of the streamgage used for this study, including the Indiana Department of Natural Resources, Division of Water and the U.S. Army Corps of Engineers, Louisville District. Special thanks are given to Tippecanoe County, Indiana, for their cooperation in this study and to the National Weather Service for their continued support of the U.S. Geological Survey flood-inundation mapping program. 



\section{Contents}

Acknowledgments ……...................................................................................................................

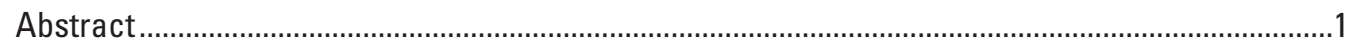

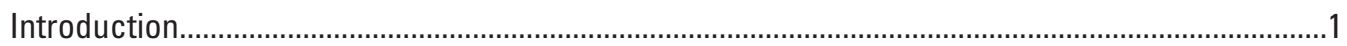

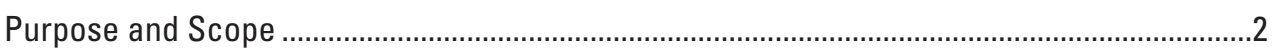

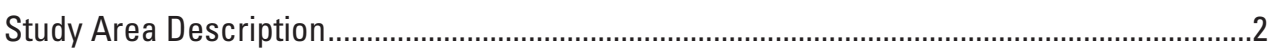

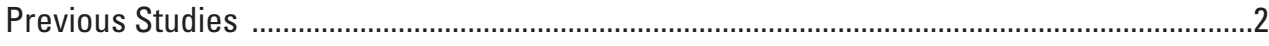

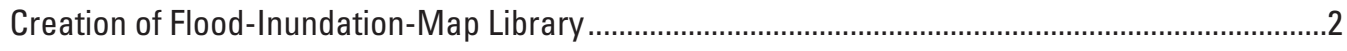

Computation of Water-Surface Profiles.................................................................................

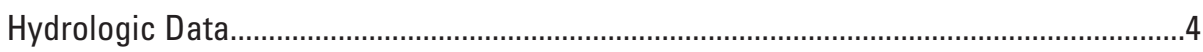

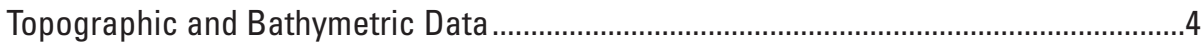

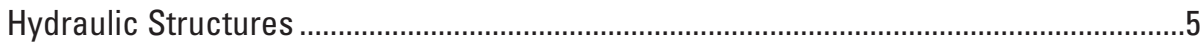

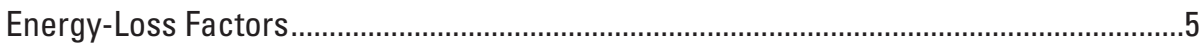

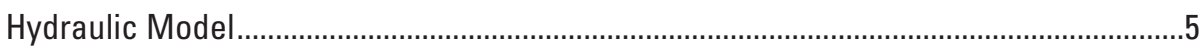

Development of Water-Surface Profiles ...........................................................................

Development of Flood-Inundation Maps ……………........................................................

Flood-Inundation Map Delivery ....................................................................................

Disclaimer For Flood-Inundation Maps ............................................................................

Uncertainties and Limitations Regarding Use of Flood-Inundation Maps .......................8

Summary

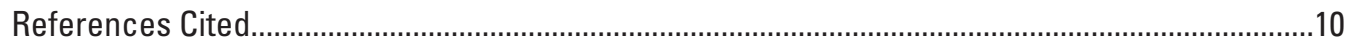

\section{Figures}

1. Map showing location of study reach for the Wabash River and location of U.S. Geological Survey streamgage 03335500.

2. Map showing example of a flood-inundation map for the Wabash River at Lafayette, Indiana, corresponding to a stage of 29.00 feet and an elevation of 532.84 feet (NAVD 88) at U.S. Geological Survey streamgage 03335500.

\section{Tables}

1. U.S. Geological Survey streamgage information for the study reach, Wabash River at Lafayette, Indiana.

2. Comparison of water-surface elevations at U.S. Geological Survey streamgage 03335500, Wabash River at Lafayette, Indiana, with water-surface elevations output from the hydraulic model.

3. Stages and corresponding discharge estimates for selected locations within the modeled reach for simulated water-surface profiles, Wabash River at Lafayette, Indiana. 


\section{Conversion Factors}

U.S. customary units to International System of Units

\begin{tabular}{lcl}
\hline \multicolumn{1}{c}{ Multiply } & By & \multicolumn{1}{c}{ To obtain } \\
\hline & Length & \\
\hline foot $(\mathrm{ft})$ & 0.3048 & meter $(\mathrm{m})$ \\
mile $(\mathrm{mi})$ & 1.609 & kilometer $(\mathrm{km})$ \\
\hline \multicolumn{3}{c}{ Area } \\
\hline square mile $\left(\mathrm{mi}^{2}\right)$ & 2.590 & square kilometer $\left(\mathrm{km}^{2}\right)$ \\
\hline \multicolumn{3}{c}{ Flow rate } \\
\hline cubic foot per second $\left(\mathrm{ft}^{3} / \mathrm{s}\right)$ & 0.02832 & cubic meter per second $\left(\mathrm{m}^{3} / \mathrm{s}\right)$ \\
\hline & Hydraulic gradient \\
\hline foot per mile $(\mathrm{ft} / \mathrm{mi})$ & 0.1894 & meter per kilometer $(\mathrm{m} / \mathrm{km})$ \\
\hline
\end{tabular}

\section{Datum}

Vertical coordinate information is referenced to either (1) stage, the height above an arbitrary datum established at a streamgage, or (2) elevation, the height above North American Vertical Datum of 1988 (NAVD 88).

Horizontal coordinate information is referenced to the North American Datum of 1983 (NAD 83). 


\title{
Flood-Inundation Maps for the Wabash River at Lafayette, Indiana
}

\author{
By Moon H. Kim
}

\section{Abstract}

Digital flood-inundation maps for an approximately 4.8-mile reach of the Wabash River at Lafayette, Indiana (Ind.) were created by the U.S. Geological Survey (USGS) in cooperation with the Indiana Office of Community and Rural Affairs. The inundation maps, which can be accessed through the USGS Flood Inundation Mapping Science web site at https://water.usgs.gov/osw/flood_inundation/, depict estimates of the areal extent and depth of flooding corresponding to selected water levels (stages) at USGS streamgage 03335500 , Wabash River at Lafayette, Ind. Current streamflow conditions for estimating near-real-time areas of inundation using USGS streamgage information may be obtained on the internet at https://waterdata.usgs.gov/in/nwis/uv?site_no $=03335500$. In addition, information has been provided to the National Weather Service (NWS) for incorporation into their Advanced Hydrologic Prediction Service (AHPS) flood-warning system (http:/water.weather.gov/ahps/). The NWS AHPS forecasts flood hydrographs at many places that are often colocated with USGS streamgages, including the Wabash River at Lafayette, Ind. NWS AHPS-forecast peak-stage information may be used with the maps developed in this study to show predicted areas of flood inundation.

For this study, flood profiles were computed for the Wabash River reach by means of a one-dimensional step-backwater model. The hydraulic model was calibrated by using the most current stage-discharge relations at USGS streamgage 03335500, Wabash River at Lafayette, Ind., and high-water marks from the flood of July 2003 (U.S. Army Corps of Engineers [USACE], 2007). The calibrated hydraulic model was then used to determine 23 water-surface profiles for flood stages at 1-foot intervals referenced to the streamgage datum and ranging from bankfull to the highest stage of the current stage-discharge rating curve. The simulated water-surface profiles were then combined with a geographic information system digital elevation model derived from light detection and ranging to delineate the area flooded at each water level.
The availability of these maps, along with internet information regarding current stage from the USGS streamgage 03335500, Wabash River at Lafayette, Ind., and forecasted high-flow stages from the NWS AHPS, will provide emergency management personnel and residents with information that is critical for flood-response activities such as evacuations and road closures, and for postflood recovery efforts.

\section{Introduction}

The Lafayette, Indiana (Ind.), metropolitan area is an urban community with an estimated population of 67,140 in 2010 (U.S. Census Bureau, 2016). The area is located in Tippecanoe County and consists of the cities of Lafayette and West Lafayette, Ind. Lafayette has experienced severe flooding numerous times, most recently in 2003, 2005, and 2009. Most flood damage was along the Wabash River, which flows through the metropolitan area. Flood plains within Lafayette and West Lafayette are highly developed and contain a mix of residential and commercial structures.

Prior to this study, officials from Lafayette, Ind., and Tippecanoe County relied on several information sources to make decisions on how to best alert the public and mitigate flood damages. One source of information is the Federal Emergency Management Agency (FEMA) Flood Insurance Study (FIS) for Tippecanoe County (FEMA, 2012). A second source is U.S. Geological Survey (USGS) streamgage 03335500, Wabash River at Lafayette, Ind., (https://waterdata.usgs.gov/in/nwis/current/?type=flow) from which current and historical water levels (stage) can be obtained. A third source is the National Weather Service (NWS) forecast of peak stage through the Advanced Hydrologic Prediction Service (AHPS) web page with the site identification of LAFI3 (http://water.weather.gov/ahps/).

Although the USGS stream stage and the NWS AHPS flood-forecast information are particularly useful for residents in the immediate vicinity of a streamgage, the information is 
generally of limited use to residents farther upstream or downstream, because the water-surface elevation is not constant along the entire stream channel. Knowledge of a water level at a streamgage is difficult to translate into depth and areal extent of flooding at points distant from the streamgage. One way to address these informational gaps is to produce a library of flood-inundation maps that are referenced to the stages recorded at the USGS streamgage. By referring to the appropriate map, emergency responders can discern the severity of flooding (depth of water and areal extent), identify roads that are or will soon be flooded, and make plans for notification or evacuation of residents in harm's way for some distance upstream and downstream from the streamgage. In addition, the capability to visualize the potential extent of flooding has been shown to motivate residents to take precautions and heed warnings that they previously might have disregarded. For this study, the USGS, in cooperation with the Indiana Office of Community and Rural Affairs, completed a project to produce a library of flood-inundation maps for the Wabash River at Lafayette, Ind.

\section{Purpose and Scope}

The purpose of this report is to describe the development of a series of estimated flood-inundation maps for the Wabash River at Lafayette, Ind. These maps were derived from a hydraulic model that was modified by the USGS in 2017. The initial hydraulic model was obtained from the U.S. Army Corps of Engineers (USACE) study that was published in 2007 (Kenneth H. Lamkin, written comm., 2012; USACE, 2007). The maps and other flood information are available on the USGS Flood Inundation Mapping Science web site and the NWS AHPS web site. Internet users can select estimated inundation maps that correspond to flood stages at USGS streamgage 03335500 and the NWS AHPS forecast peak stage for Wabash River at Brown Street Overlook (LAFI3).

The scope and extent of the study for hydraulic modeling was larger (not shown) than the mapped area (USACE, 2007). However, the mapping of the study reach was limited to the Wabash River reach extending about 2.5 miles (mi) upstream of USGS streamgage 03335500 , which is located on the western bank of the river and on the downstream side of the Brown St. abutment and about $2.3 \mathrm{mi}$ downstream of the streamgage. Due to uncertainty and limitation of the hydraulic modeling and the mapping methods, an additional two small study area limit lines were added; both of these lines are located approximately 1.3 mi upstream of the streamgage and $0.7 \mathrm{mi}$ east of the main channel (fig. 1). In this report, the term "study reach" refers to the mapped reach, which is a subset of the modeled reach. The maps cover a range in stage from 7 to 29 feet (ft) with respect to the gage datum (table 1; USGS, 2016c). The 7-ft stage is approximately bankfull and is defined by the NWS as the "action stage" or that stage which, when reached by a rising stream, requires the NWS or a partner to take some type of mitigation action in preparation for possible significant hydrologic activity. The 11-ft, 18-ft, and 26-ft stages are defined by the National Weather Service (2017) as flood stage, moderate flood stage, and major flood stage, respectively. The 29-ft stage is approximately the highest stage of the current stage-discharge rating curve (rating number 45.0) at the streamgage.

\section{Study Area Description}

The study reach of the Wabash River is in central Indiana. The drainage area is 7,255 square miles $\left(\mathrm{mi}^{2}\right)$ at the upstream end of the study reach, 7,267 $\mathrm{mi}^{2}$ at the USGS streamgage 03335500, Wabash River at Lafayette, Ind., and 7,272 $\mathrm{mi}^{2}$ at the downstream extent of the study reach (USGS, 2016a). The stream flows generally southwest before entering the city limits. There are no major tributaries to the Wabash River that join the main stem in the study reach as it flows through Lafayette. The basin terrain is generally flat. The study reach is approximately 4.8 -mi long, has an average top-of-bank channel width of about $470 \mathrm{ft}$ and an average channel slope of $0.00021(1.1 \mathrm{ft} / \mathrm{mi})$. The population of Lafayette, Ind. has increased about 19 percent from 56,397 to 67,140 between 2000 and 2010 (U.S. Census Bureau, 2016). The main channel within the study reach has six road bridges, a pedestrian bridge, and a railroad bridge crossing the main channel or the adjacent flood plain. In addition, a flood-control levee exists along the main channel (on the left bank, just upstream of the US 231 bridge) of the study reach near the Lafayette Wastewater Treatment plant (fig. 1).

\section{Previous Studies}

The current FIS for Lafayette, Ind., was revised in 2012. The 2012 FIS provided information about the 1.0-percent and 0.2-percent annual exceedance probability water-surface profiles and associated flood-plain maps for the Wabash River. Estimates of the peak discharges for the 1.0-percent and 0.2 -percent annual exceedance probability floods were documented for the Wabash River at Lafayette, Ind. (listed as "At Brown Street" in FIS) with discharges of 95,000 cubic feet per second and 131,000 cubic feet per second, respectively; the drainage area for the above location was listed as 7,267 $\mathrm{mi}^{2}$ (FEMA, 2012).

\section{Creation of Flood-Inundation-Map Library}

The USGS has standardized the procedures for creating flood-inundation maps for flood-prone communities (USGS, $2016 \mathrm{~b}$ ) so that the process followed and products produced are similar regardless of which USGS office is responsible for the work. Tasks specific to construction of the maps were (1) compilation of flow data from streamgage 03335500 , (2) collection 


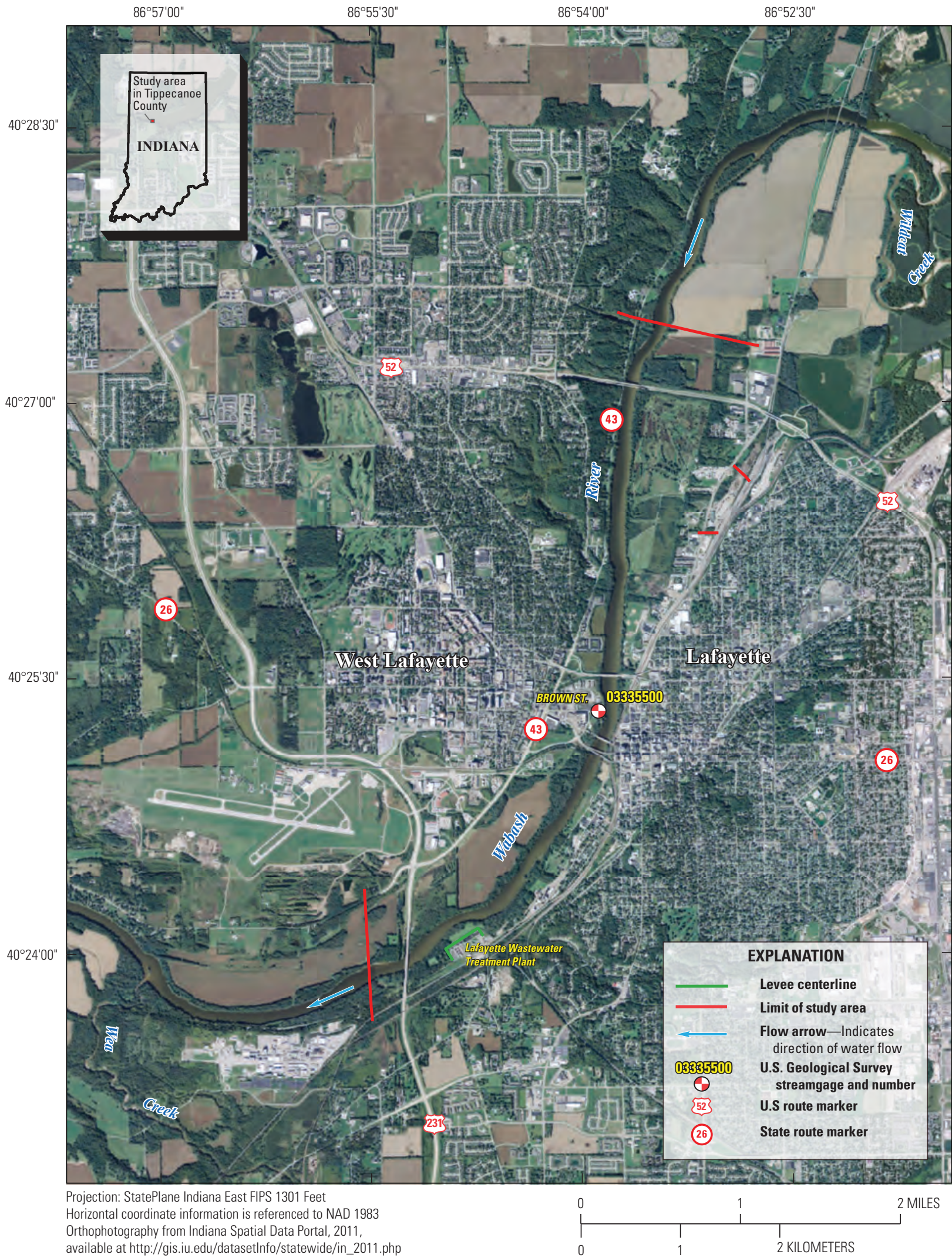

Figure 1. Location of study reach for the Wabash River and location of U.S. Geological Survey streamgage 03335500. 
Table 1. U.S. Geological Survey streamgage information for the study reach, Wabash River at Lafayette, Indiana.

[Data from U.S. Geological Survey (2016c); mi², square miles; NAD 83, North American Datum of 1983; NAVD 88, North American Vertical Datum of 1988 ; ft, feet]

\begin{tabular}{|c|c|c|c|c|c|c|c|}
\hline Streamgage name & $\begin{array}{c}\text { Streamgage } \\
\text { number }\end{array}$ & $\begin{array}{c}\text { Drainage } \\
\text { area } \\
\left(\mathrm{mi}^{2}\right)\end{array}$ & $\begin{array}{l}\text { Latitude } \\
\text { (NAD 83) }\end{array}$ & $\begin{array}{l}\text { Longitude } \\
\text { (NAD 83) }\end{array}$ & $\begin{array}{l}\text { Streamgage } \\
\text { datum } \\
\text { (ft, NAVD 88) }\end{array}$ & Period of record & $\begin{array}{c}\text { Maximum flood } \\
\text { stage } \\
\text { (ft, date) }\end{array}$ \\
\hline
\end{tabular}

of topographic data and geometric data (for structures and bridges) throughout the study reach and modeled reach, (3) estimation of energy-loss factors (roughness coefficients) in the stream channel and flood plain, (4) computation of watersurface profiles by use of the USACE Hydrologic Engineering Center-River Analysis System (HEC-RAS) computer program (USACE, 2010), (5) production of estimated flood-inundation maps at various stream stages by use of the USACE HECGeoRAS computer program (USACE, 2012) and a geographic information system (GIS) computer program called ArcGIS (Esri, 2013), and (6) development of a web interface that links to USGS real-time streamgage information and NWS AHPS forecast peak stage to facilitate the display of user-selected flood-inundation maps on the internet. Some of the tasks listed above were conducted and managed by the USACE, including the development and the calibration of the original hydraulic model (USACE, 2007). The USGS provided support and guidance in collection of hydrologic data, calibration of the final model used in this study, development of floodinundation GIS layers, and development of the web interface mentioned above. The USGS provided quality-control reviews of the hydraulic model and its related datasets and resulting flood-inundation maps. The methods used are generally cited from previously published reports (Bales and others, 2007; Whitehead and Ostheimer, 2009). If techniques varied significantly from previously documented methods in response to local hydrologic conditions or availability of data, they are described in detail in this report. Twenty-three maps were produced for water levels referenced to the stage at USGS streamgage 03335500 , Wabash River at Lafayette, Ind., and the water levels shown on the maps range from approximately bankfull ( $7 \mathrm{ft}$ ) to the approximately highest stage $(29 \mathrm{ft})$ on the current stage-discharge rating curve.

\section{Computation of Water-Surface Profiles}

The water-surface profiles used to produce the 23 flood-inundation maps in this study were simulated by using
HEC-RAS, version 4.1 (USACE, 2010). HEC-RAS is a one-dimensional step-backwater model for simulation of water-surface profiles with gradually varied, steady-state, or unsteady-state flow computation options. The HEC-RAS analysis for this study was completed with the steady-state flow computation option.

\section{Hydrologic Data}

The study area hydrologic network consists of one streamgage (fig. 1), which has been in operation, on and off, since 1901 (table 1). Water level (stage) is measured continuously at this site, and continuous records of streamflow are computed. All water-surface elevations are referenced to the North American Vertical Datum of 1988 (NAVD 88). The streamgage is equipped with a satellite radio transmitter that allows data to be transmitted routinely on the internet within an hour of collection. Flow data can be accessed at https://waterdata.usgs.gov/in/nwis/current/?type=flow by selecting the appropriate streamgage number.

Steady-flow data consisted of flow regime, boundary conditions (normal depth), and peak-discharge information. The steady-flow data for the model were obtained from field measurements of streamflow at USGS streamgage 03335500 , Wabash River at Lafayette, Ind. All computations were based on discharge values with known stages from actual streamflow measurements or stage-discharge relations (rating number 45.0).

\section{Topographic and Bathymetric Data}

For the original USACE hydraulic model analysis, channel cross sections for the model were developed by utilizing the data from an existing HEC-2 model (HEC-2, Water Surface Profiles) that was downloaded from the Indiana Department of Natural Resources, Division of Water web site (http://dnrmaps.dnr.in.gov/appsphp/model/index.php) and a digital terrain model that was converted from 2 -ft contour 
mapping obtained from Tippecanoe County officials. Cross sections for the model were modified and (or) added as needed. For new cross sections that were not in the HEC-2 model, the channel bathymetry data were interpolated between existing cross sections using available tools (USACE, 2007). A detailed description of the methods used to acquire and process the topographic and bathymetric data can be found in Bales and others (2007).

For the purpose of mapping, the digital elevation model (DEM) data that were derived from the light detection and ranging (lidar) data were used to create flood-extent polygons and depth grids. Because lidar data cannot provide ground elevations below a stream's water surface, depth information within the stream channel contained in the depth grids may be shallower than the actual depth. Additional information regarding the DEM and lidar data can be found in the following section called "Development of Flood-Inundation Maps."

\section{Hydraulic Structures}

Various man-made drainage structures (bridges, culverts, roadway embankments, and levees) in and along the Wabash River affect or have the potential to affect water-surface elevations during floods. To properly account for these features in the model, structural dimensions for most of the bridges within the modeled reach were obtained from the Indiana Department of Transportation, the Tippecanoe County Highway Department, and Norfolk Southern Railroad. When the US 231 bridge (near the downstream end of the study reach) was being constructed in the late 1990s, detailed modeling analyses were performed to account for the zone of influence of changing topography near the bridge, which resulted in modifying the elevation of levees that protect a wastewater treatment facility located about one half-mile upstream of the bridge (USACE, 2007, fig. 2). An explanation of how these levees are shown on maps can be found in the section titled "Flood-Inundation Map Delivery."

\section{Energy-Loss Factors}

Hydraulic analyses require the estimation of energy losses that result from frictional resistance exerted by a channel on flow. Field observations, aerial photos, and engineering experience were used to select initial channel and flood-plain friction coefficients (USACE, 2007). These friction coefficients, commonly called Manning's roughness coefficients or Manning's $n$ values, account for energy (friction) loss in the model (Arcement and Schneider, 1989). As part of the calibration process for mapping purposes, the initial $n$ values were varied by flow roughness factors (ranging from 0.8 to 1.18 ) in the model and adjusted until the differences between simulated and observed water-surface elevations at the streamgage were minimized. The final Manning's $n$ values ranged from 0.024 to 0.038 for the main channel and from 0.028 to 0.094 for the overbank areas modeled in this analysis.

\section{Hydraulic Model}

The HEC-RAS analysis for this study was done by using the steady-state flow computation option. Steady-state flow data consisted of flow regime, boundary conditions, and peak flows that produced water-surface elevations at the streamgage cross section that matched target water-surface elevations. These target elevations coincided with even 1-ft increments of stage, referenced to the local gage datum. Subcritical (tranquil) flow regime was assumed for the simulations. Normal depth was used as the reach's downstream boundary condition with slope value of 0.00028 . The value for the slope was estimated from the flood-profile plots that were included in the FIS (FEMA, 2012).

The initial HEC-RAS hydraulic model obtained from USACE was calibrated with high-water-marks from a flood event in July 2003 (USACE, 2007). The hydraulic model was then modified by the USGS and calibrated to the most current stage-discharge relation (rating number 45.0) at USGS streamgage 03335500, Wabash River at Lafayette, Ind. Model calibration was accomplished by adjusting Manning's $n$ values until the results of the hydraulic computations closely agreed with the known flood discharge and stage values. Differences between measured and simulated water levels for measured or rated flows at USGS streamgage 03335500 were less than or equal to $0.5 \mathrm{ft}$ (table 2). The results demonstrate that the model is capable of simulating reasonable water levels over a wide range of flows at or near the streamgage. Details on techniques used in model development and calibration can be found in Bales and others (2007). The datasets and model input used in this study are available through a data release at https://doi.org/10.5066/F7PC31BN (Kim, 2018).

\section{Development of Water-Surface Profiles}

The calibrated hydraulic model was used to generate water-surface profiles for 23 stages at 1-ft intervals between $7 \mathrm{ft}$ and $29 \mathrm{ft}$ as referenced to USGS streamgage 03335500 , Wabash River at Lafayette, Ind. These stages correspond to elevations of $510.84 \mathrm{ft}$ and $532.84 \mathrm{ft}$, NAVD 88, respectively. Discharges corresponding to the various stages were obtained from the most current stage-discharge relation (rating number 45.0) at the Wabash River streamgage.

Discharges for all profiles were selected with the assumption that there are no significant tributary inflows within the 4.8-mi study reach. The discharges were estimated to be uniform and steady throughout the study reach. However, because there were some differences in drainage area between the location at the downstream extent and at the upstream extent of the modeled reach, four change-of-flow locations in the hydraulic model were included. Discharge at each change-of-flow location in the model was estimated by, first, calculating cubic feet per second per square mile (referred to as CFSM) that corresponded to the measured discharges at USGS streamgage 03335500, then multiplying this CFSM value by drainage area at each corresponding location in the model (table 3 ). The 


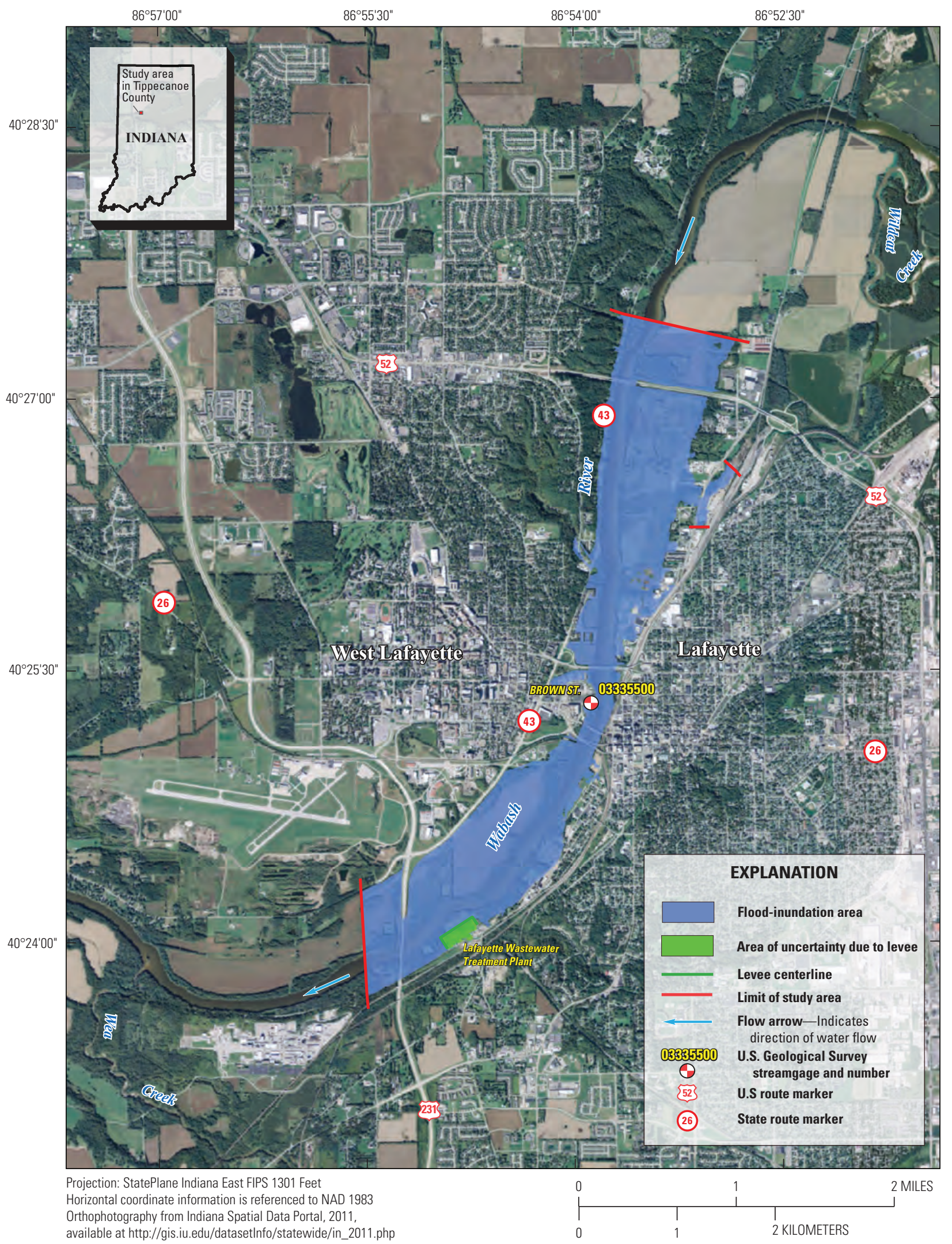

Figure 2. Example of a flood-inundation map for the Wabash River at Lafayette, Indiana, corresponding to a stage of 29.00 feet and an elevation of 532.84 feet (NAVD 88) at U.S. Geological Survey streamgage 03335500. 
Table 2. Comparison of water-surface elevations at U.S. Geological Survey streamgage 03335500, Wabash River at Lafayette, Indiana, with water-surface elevations output from the hydraulic model.

[ft, feet; NAVD 88, North American Vertical Datum of 1988]

\begin{tabular}{rccc}
\hline $\begin{array}{c}\text { Stage } \\
\text { (ft) }\end{array}$ & $\begin{array}{c}\text { Measured } \\
\text { water-surface } \\
\text { elevation } \\
\text { (ft, NAVD 88) }\end{array}$ & $\begin{array}{c}\text { Modeled } \\
\text { water-surface } \\
\text { elevation } \\
\text { (ft, NAVD 88) }\end{array}$ & $\begin{array}{c}\text { Elevation } \\
\text { difference } \\
\text { (ft) }\end{array}$ \\
\hline 7.00 & 510.84 & 511.19 & 0.35 \\
8.00 & 511.84 & 512.33 & 0.49 \\
9.00 & 512.84 & 513.34 & 0.50 \\
10.00 & 513.84 & 514.27 & 0.43 \\
11.00 & 514.84 & 515.16 & 0.32 \\
12.00 & 515.84 & 516.03 & 0.19 \\
13.00 & 516.84 & 516.87 & 0.03 \\
14.00 & 517.84 & 517.71 & -0.13 \\
15.00 & 518.84 & 518.56 & -0.28 \\
16.00 & 519.84 & 519.68 & -0.16 \\
17.00 & 520.84 & 520.73 & -0.11 \\
18.00 & 521.84 & 522.02 & 0.18 \\
19.00 & 522.84 & 522.94 & 0.10 \\
20.00 & 523.84 & 524.09 & 0.25 \\
21.00 & 524.84 & 524.74 & -0.10 \\
22.00 & 525.84 & 525.62 & -0.22 \\
23.00 & 526.84 & 526.75 & -0.09 \\
24.00 & 527.84 & 527.71 & -0.13 \\
25.00 & 528.84 & 528.74 & -0.10 \\
26.00 & 529.84 & 529.77 & -0.07 \\
27.00 & 530.84 & 530.79 & -0.05 \\
28.00 & 531.84 & 531.75 & -0.09 \\
29.00 & 532.84 & 532.67 & -0.17 \\
\hline & & &
\end{tabular}

CFSM is defined as the average number of cubic feet of water per second flowing from each square mile of area drained by a stream, assuming that the runoff is distributed uniformly in time and area.

\section{Development of Flood-Inundation Maps}

Flood-inundation maps were created for a reach of the Wabash River at Lafayette, Ind. The maps were created in a GIS by combining the water-surface profiles and DEM data (an example is shown on fig. 2). The DEM data for Lafayette, Ind. (Tippecanoe County lidar) were collected for the "2011-2013 Indiana Orthophotography (RGBI), LiDAR and
Elevation" program (http://gis.iu.edu/datasetInfo/statewide/ in_2011.php). The lidar data for Tippecanoe County, Ind. have horizontal resolution of $3.3 \mathrm{ft}$ and vertical accuracy of $0.98 \mathrm{ft}$ at a 95-percent confidence level based on a root mean squared error of $0.49 \mathrm{ft}$ for the "open terrain" land-cover category. Although a finer resolution of the DEM was possible given the accuracy of the lidar data, the final DEM that was used for mapping was resampled to a grid-cell size of $10 \mathrm{ft}$ by $10 \mathrm{ft}$ to decrease the GIS processing time.

Estimated flood-inundation boundaries for each simulated profile were developed with HEC-GeoRAS software (USACE, 2012). HEC-GeoRAS is a set of procedures, tools, and utilities for processing geospatial data in ArcGIS using a graphical user interface (Esri, 2013). The interface allows the preparation of geometric data for import into HEC-RAS and processes simulation results exported from HEC-RAS (USACE, 2010). USGS personnel then modified the HECGeoRAS results to ensure a hydraulically reasonable transition of the boundary between modeled cross sections relative to the contour data for the land surface (Whitehead and Ostheimer, 2009). The resulting inundation maps have a vertical accuracy of about plus or minus $1.0 \mathrm{ft}$.

Any inundated areas that were detached from the main channel were examined to identify subsurface connections with the main river, such as through culverts under roadways. Where such connections were found, the mapped inundated areas were retained in their respective flood maps; otherwise, the erroneously delineated parts of the flood extent were deleted. The flood-inundation areas are overlaid on highresolution, georeferenced aerial photographs of the study area. Bridge surfaces are displayed as inundated regardless of the actual water-surface elevation in relation to the lowest structural chord of the bridge or the bridge deck. Estimates of water depth can be obtained from the depth-grid data that are included with the presentation of the flood maps on an interactive USGS mapping application described in the following section, "Flood-Inundation Map Delivery."

\section{Flood-Inundation Map Delivery}

The flood-inundation maps from this study depict estimates of the areal extent and depth of flooding corresponding to selected water levels (stages) at the USGS streamgage 03335500, Wabash River at Lafayette, Ind. The current study documentation is available online at the USGS Publications Warehouse (https://doi.org/10.3133/sir20185017). In addition, a Flood Inundation Mapping Science web site has been established to provide a portal for USGS floodinundation study information to be made accessible to the public at https://water.usgs.gov/osw/flood_inundation/. That web portal has a link (https://wim.usgs.gov/FIMI/ FloodInundationMapper.html) to a mapping application that presents map libraries and provides detailed information on flood extents and depths for selected sites. The mapping application enables the production of customized flood-inundation maps from the map library for the Wabash River at Lafayette, 
Table 3. Stages and corresponding discharge estimates for selected locations within the modeled reach for simulated water-surface profiles, Wabash River at Lafayette, Indiana.

$\left[\mathrm{mi}^{2}\right.$, square miles; $\mathrm{ft}^{3} / \mathrm{s}$, cubic feet per second; USGS, U.S. Geological Survey]

\begin{tabular}{|c|c|c|c|c|c|c|c|c|c|c|c|c|c|}
\hline \multirow{3}{*}{ Location } & \multirow{3}{*}{$\begin{array}{c}\text { Drainage } \\
\text { area }^{1} \\
\left(\mathrm{mi}^{2}\right)\end{array}$} & \multicolumn{12}{|c|}{ Stage (in feet above streamgage datum) } \\
\hline & & 7.00 & 8.00 & 9.00 & 10.00 & 11.00 & 12.00 & 13.00 & 14.00 & 15.00 & 16.00 & 17.00 & 18.00 \\
\hline & & \multicolumn{12}{|c|}{ Discharge $\left(\mathrm{ft}^{3} / \mathrm{s}\right)$} \\
\hline $\begin{array}{l}\text { Upstream end of the } \\
\text { modeled reach }\end{array}$ & 6,383 & 7,907 & 9,561 & 11,320 & 13,178 & 15,130 & 17,171 & 19,300 & 21,583 & 24,034 & 26,780 & 29,864 & 33,891 \\
\hline $\begin{array}{l}\text { Downstream of Wildcat } \\
\text { Creek }\end{array}$ & 7,203 & 8,922 & 10,790 & 12,774 & 14,871 & 17,073 & 19,377 & 21,779 & 24,356 & 27,121 & 30,221 & 33,701 & 38,245 \\
\hline $\begin{array}{l}\text { USGS streamgage } \\
\quad 03335500\end{array}$ & 7,267 & 9,002 & 10,885 & 12,888 & 15,003 & 17,225 & 19,550 & 21,973 & 24,572 & 27,362 & 30,489 & 34,000 & 38,585 \\
\hline $\begin{array}{l}\text { Downstream of Wea } \\
\text { Creek }\end{array}$ & 7,443 & 9,220 & 11,149 & 13,200 & 15,366 & 17,642 & 20,023 & 22,505 & 25,167 & 28,025 & 31,228 & 34,823 & 39,519 \\
\hline
\end{tabular}

${ }^{1}$ Drainage area information was obtained from a USGS web application (USGS, 2016a).

Ind. At the map library site, each stream reach displayed contains further links to National Water Information System web graphs of the current stage and streamflow at USGS streamgage 03335500 to which the inundation maps are referenced. A link also is provided to the NWS AHPS site (http:/ water.weather.gov/ahps/) so that the user can obtain applicable information on forecast peak stage. The NWS routinely issues forecast stage year-round at this site. The estimated floodinundation maps are displayed in sufficient detail to note the extent of flooding with respect to individual structures so that preparations for flooding and decisions for emergency response can be performed efficiently. Depending on the flood magnitude, roadways are shown as shaded (inundated and likely impassable) or not shaded (dry and passable) to facilitate emergency planning and use. Bridges are shaded - that is, shown as inundated - regardless of the flood magnitude. A shaded building should not be interpreted to mean that the structure is completely submerged; rather that bare earth surfaces near the building are inundated. In these instances, the water depth (as indicated in the mapping application by clicking the cursor over an inundated area) near the building would be an estimate of the water level inside the structure, unless flood-proofing measures had been implemented.

Starting at a stage of $11 \mathrm{ft}$, which is defined as flood stage by NWS, an overbank area is shown with different color shading than the main-channel flood extents to indicate that this is an area of uncertainty due to the levee. This area is generally protected by the levee but could become inundated if the levee was to breach or overtop. The flood-inundation maps show flooding in this leveed area as the "worst-case" scenario, that is, the maximum flood extent that would occur if the levee did not exist. Water depth information has not been provided and not displayed for areas behind the levee.

\section{Disclaimer For Flood-Inundation Maps}

The flood-inundation maps should not be used for navigation, regulatory, permitting, or other legal purposes. The USGS provides these maps "as-is" for a quick reference, emergency planning tool but assumes no legal liability or responsibility resulting from the use of this information.

\section{Uncertainties and Limitations Regarding Use of Flood-Inundation Maps}

Although the flood-inundation maps represent the boundaries of inundated areas with a distinct line, some uncertainty is associated with these maps (Bales and Wagner, 2009). The flood boundaries shown were estimated on the basis of water stages and streamflows at selected USGS streamgages. Watersurface elevations along the stream reaches were estimated by steady-state hydraulic modeling, assuming unobstructed flow, and using streamflows and hydrologic conditions anticipated at the USGS streamgage(s). The hydraulic model reflects the land-cover characteristics and any bridge, dam, levee, or other hydraulic structures existing as of September 2007. Unique meteorological factors (timing and distribution of precipitation) may cause actual streamflows along the modeled reach to vary from those assumed during a flood, which may lead to deviations in the water-surface elevations and inundation boundaries shown. Additional areas may be flooded due to unanticipated conditions such as changes in the streambed 
Table 3. Stages and corresponding discharge estimates for selected locations within the modeled reach for simulated watersurface profiles, Wabash River at Lafayette, Indiana.-Continued

$\left[\mathrm{mi}^{2}\right.$, square miles; $\mathrm{ft}^{3} / \mathrm{s}$, cubic feet per second; USGS, U.S. Geological Survey]

\begin{tabular}{|c|c|c|c|c|c|c|c|c|c|c|c|c|}
\hline \multirow{3}{*}{ Location } & \multirow{3}{*}{$\begin{array}{c}\text { Drainage } \\
\text { area }^{1} \\
\left(\mathbf{m i}^{2}\right)\end{array}$} & \multicolumn{11}{|c|}{ Stage (in feet above streamgage datum) } \\
\hline & & 19.00 & 20.00 & 21.00 & 22.00 & 23.00 & 24.00 & 25.00 & 26.00 & 27.00 & 28.00 & 29.00 \\
\hline & & \multicolumn{11}{|c|}{ Discharge $\left(\mathrm{ft}^{3} / \mathrm{s}\right)$} \\
\hline $\begin{array}{l}\text { Upstream end of the } \\
\text { modeled reach }\end{array}$ & 6,383 & 38,188 & 42,753 & 47,607 & 52,754 & 58,197 & 63,939 & 69,983 & 76,334 & 82,993 & 89,964 & 97,249 \\
\hline $\begin{array}{l}\text { Downstream of Wildcat } \\
\text { Creek }\end{array}$ & 7,203 & 43,094 & 48,245 & 53,723 & 59,531 & 65,673 & 72,153 & 78,974 & 86,140 & 93,655 & 101,521 & 109,742 \\
\hline $\begin{array}{l}\text { USGS streamgage } \\
\quad 03335500\end{array}$ & 7,267 & 43,477 & 48,674 & 54,201 & 60,060 & 66,257 & 72,794 & 79,676 & 86,906 & 94,487 & 102,423 & 110,717 \\
\hline $\begin{array}{l}\text { Downstream of Wea } \\
\text { Creek }\end{array}$ & 7,443 & 44,530 & 49,853 & 55,513 & 61,515 & 67,861 & 74,557 & 81,605 & 89,010 & 96,775 & 104,904 & 113,399 \\
\hline
\end{tabular}

${ }^{1}$ Drainage area information was obtained from a USGS web application (USGS, 2016a).

elevation or roughness, backwater into major tributaries along a main-stem river, or backwater from localized debris or ice jams. The accuracy of the floodwater extent portrayed on these maps will vary with the accuracy of the digital elevation model used to simulate the land surface.

If this series of flood-inundation maps will be used in conjunction with NWS river forecasts, the user should be aware of additional uncertainties that may be inherent or factored into NWS forecast procedures. The NWS uses forecast models to estimate the quantity and timing of water flowing through selected stream reaches in the United States. These forecast models (1) estimate the amount of runoff generated by precipitation and snowmelt, (2) simulate the movement of floodwater as it proceeds downstream, and (3) predict the flow and stage (and water-surface elevation) for the stream at a given location (AHPS forecast point) throughout the forecast period (every 6 hours and 3 to 5 days out in many locations). For more information on AHPS forecasts, please see: http://water.weather.gov/ahps/pcpn_and_river_forecasting.pdf.

The flood maps show a levee segment in the downstream end of the study reach that has uncertain effects on the extent and depth of flooding that could occur on the landward side of these levees (fig. 2). The extent and depth of flooding will vary with the elevation of the water surface in the river. Because the actual extent and depth of flooding in these leveed areas during a particular flood event are uncertain, the flood-inundation maps show flooding as the "worst-case" scenario, that is, the maximum flood extent that would occur if the levee did not exist. The "areas of uncertainty due to a levee" are displayed in different color than the main-channel flood extents to reflect this uncertainty. Additional uncertainties and limitations pertinent to this study may be described elsewhere in this report.

\section{Summary}

Estimated flood-inundation maps were developed in cooperation with the Indiana Office of Community and Rural Affairs for the Wabash River at Lafayette, Indiana, from about 2.5-miles upstream of USGS streamgage 03335500, which is located on the downstream side of the Brown St. western-bank abutment to about 2.3-miles downstream of the streamgage.

The maps were developed using the U.S. Army Corps of Engineers' Hydrologic Engineering Center's River Analysis System (HEC-RAS) and HEC-GeoRAS programs and Esri's ArcGIS program to compute water-surface profiles and to delineate estimated flood-inundation areas for selected stream stages. The simulated water-surface profiles were then combined with a geographic information system digital elevation model derived from light detection and ranging data to delineate estimated flood-inundation areas as shapefile polygons and depth grids for each profile. These flood-inundation polygons were overlaid on high-resolution, georeferenced aerial photographs of the study area. The maps show estimated (shaded) flood-inundation areas of the study area for stream stages between 7 feet and 29 feet at the Wabash River at Lafayette streamgage. The flood maps are available through a mapping application that can be accessed on the USGS Flood Inundation Mapping Science web site (https://water.usgs.gov/ osw/flood_inundation).

Interactive use of the maps on this mapping application can give users a general indication of depth of water at any point by using the mouse cursor to click within the shaded areas. These maps, in conjunction with the real-time stage data from the USGS streamgage 03335500 and National Weather 
Service Advanced Hydrologic Prediction Service floodstage forecasts for Wabash River at Brown Street Overlook (LAFI3), will help to guide the general public in taking individual safety precautions and provide emergency management personnel with a tool to efficiently manage emergency flood operations and postflood recovery efforts.

\section{References Cited}

Arcement, G.J., Jr., and Schneider, V.R., 1989, Guide for selecting Manning's roughness coefficients for natural channels and flood plains: U.S. Geological Survey Water-Supply Paper 2339, 38 p.

Bales, J.D., and Wagner, C.R., 2009, Sources of uncertainty in flood inundation maps: Journal of Flood Risk Management, v. 2 , no. 2 , p. $139-147$.

Bales, J.D., Wagner, C.R., Tighe, K.C., and Terziotti, Silvia, 2007, LiDAR-derived flood-inundation maps for realtime flood-mapping applications, Tar River Basin, North Carolina: U.S. Geological Survey Scientific Investigations Report 2007-5032, 42 p.

Esri, 2013, ArcGIS, accessed November 4, 2013, at http://www.esri.com/software/arcgis/.

Federal Emergency Management Agency [FEMA], 2012, Flood insurance study for Tippecanoe County, Indiana and Incorporated Area: Washington D.C., Flood Insurance Study Number 18157CV000B, $112 \mathrm{p}$.

Kim, M.H., 2018, Geospatial data and surface-water model archive for a flood-inundation mapping study of the Wabash River at Lafayette, Indiana: U.S. Geological Survey data release, accessed March 2018, at https://doi.org/10.5066/ F7PC31BN.
U.S. Army Corps of Engineers [USACE], Hydrologic Engineering Center, 2010, HEC-RAS river analysis systemHydraulic reference manual, version 4.1 [variously paged]: accessed June 16, 2016, at http://www.hec.usace.army.mil/ software/hec-ras/downloads.aspx.

U.S. Army Corps of Engineers [USACE], Hydrologic Engineering Center, 2012, HEC-GeoRAS, version 10.1, GIS tools for support of HEC-RAS using ArcGIS, user's manual [variously paged]: accessed June 16, 2016, at http://www.hec.usace.army.mil/software/hec-georas/ downloads.aspx.

U.S. Army Corps of Engineers [USACE], Louisville District, 2007, Wabash River Analysis-Phase I Tippecanoe County, Indiana: Planning Assistance to States Study_FINAL REPORT, $54 \mathrm{p}$.

U.S. Census Bureau, 2016, American FactFinder-Lafayette city, Indiana: accessed November 10, 2016, at https://factfinder.census.gov/faces/nav/jsf/pages/ community_facts.xhtml.

U.S. Geological Survey [USGS], 2016a, StreamStats for Indiana streams, accessed November 10, 2016, at https://water.usgs.gov/osw/streamstats/indiana.html.

U.S. Geological Survey [USGS], 2016b, USGS flood inundation mapping science-Flood inundation mapping program: U.S. Geological Survey, accessed November 10, 2016, at https://water.usgs.gov/osw/flood_inundation.

U.S. Geological Survey [USGS], 2016c, USGS surface-water data for the Nation: U.S. Geological Survey, accessed November 10, 2016, at https://waterdata.usgs.gov/nwis/sw.

Whitehead, M.T., and Ostheimer, C.J., 2009, Development of a flood-warning system and flood-inundation mapping for the Blanchard River in Findlay, Ohio: U.S. Geological Survey Scientific Investigations Report 2008-5234, 9 p., 11 pls. 



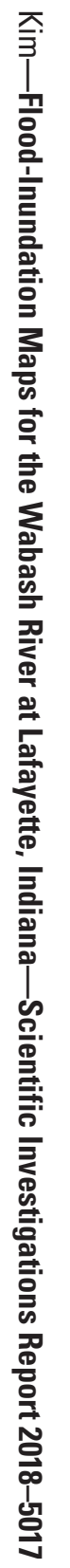

